\title{
Altertoxins with Quorum Sensing Inhibitory Activities from The Marine-Derived Fungus Cladosporium sp. KFD33
}

\author{
Fei Zhang ${ }^{1,2,+}$, Liman Zhou ${ }^{1,+}$, Fandong Kong ${ }^{1,+}$, Qingyun Ma ${ }^{1}$, Qingyi Xie ${ }^{1}$, Jiuhui Li ${ }^{1}$, \\ Haofu Dai ${ }^{1}$, Lei Guo ${ }^{2, * \mathbb{B}}$ and Youxing Zhao ${ }^{1, *}$ \\ 1 Hainan Key Laboratory of Research and Development of Natural Product from Li Folk Medicine, Institute of \\ Tropical Bioscience and Biotechnology, Chinese Academy of Tropical Agricultural Sciences, Haikou 571101, \\ China; MarchFay@163.com (F.Z.); zhouliman88@126.com (L.Z.); kongfandong@itbb.org.cn (F.K.); \\ maqingyun@itbb.org.cn (Q.M.); xieqingyi@itbb.org.cn (Q.X.); lijiuhui@itbb.org.cn (J.L.); \\ daihaofu@itbb.org.cn (H.D.) \\ 2 Jiangsu Key Laboratory of Marine Bioresources and Environment, Co-Innovation Center of Jiangsu Marine \\ Bio-industry Technology, Jiangsu Ocean University, Lianyungang 222005, China \\ * Correspondence: guol@jou.edu.cn (L.G.); zhaoyouxing@itbb.org.cn (Y.Z.); Tel.: +86-159-5072-6013 (L.G.); \\ +86-898-6698-9095 (Y.Z.) \\ + These authors contributed equally to this paper.
}

Received: 30 December 2019; Accepted: 17 January 2020; Published: 19 January 2020

\begin{abstract}
Five new perylenequinone derivatives, altertoxins VIII-XII (1-5), as well as one known compound cladosporol I (6), were isolated from the fermentation broth of the marine-derived fungus Cladosporium sp. KFD33 from a blood cockle from Haikou Bay, China. Their structures were determined based on spectroscopic methods and ECD spectra analysis along with quantum ECD calculations. Compounds 1-6 exhibited quorum sensing inhibitory activities against Chromobacterium violaceum CV026 with MIC values of 30, 30, 20, 30, 20 and $30 \mu \mathrm{g} /$ well, respectively.
\end{abstract}

Keywords: Cladosporium sp.; altertoxins; quorum sensing inhibitory activity

\section{Introduction}

The unremitting discovery of antibiotics showed a promising prospect for the bacterial infections, but also resulted in the serious resistance of antibiotics. Bacteria have evolved a variety of resistance mechanisms [1,2]. Quorum sensing (QS) is the regulation of gene expression in response to fluctuations in cell-population density among diverse bacterial species [3]. QS controls the production of virulence factors in bacteria in a population density dependent manner through intercellular communication mechanism [3]. QS inhibitors (QSIs) can inhibit the QS mechanism and attenuate virulence without influencing bacterial growth. Thus, QSIs can be used to disarm pathogens in the host and are not easy to cause bacterial resistance compared to conventional antibiotics [4,5]. The search for efficient QSIs is supposed to be an effective method to solve problems of bacterial infection and antibiotic resistance. Based on this, a screening system has been established for searching of QSIs [6]. Due to the special environmental conditions, marine-derived fungi, as a rich source of various compounds with complex structures and excellent activities, have attracted more and more attentions [7]. Our previous research on new bioactive metabolites from the marine-derived fungi has led to the isolation and identification of many new QSIs, such as aculene $\mathrm{E}$ and penicitor $\mathrm{B}$, aculene $\mathrm{C}$, aculene $\mathrm{D}$, aspergillumarins $\mathrm{A}-\mathrm{B}$ [8], asperochrin D, asperochrin F, (3R,4R)-4,7-dihydroxymellein, asperochrin A, and asteltoxin [9]. As our ongoing research, the fungus Cladosporium sp. KFD33 was isolated from a blood cockle from Haikou Bay, China. The EtOAc extract of the fermentation broth of this fungus showed obvious QS inhibitory 
activity against Chromobacterium violaceum CV026. Subsequent chemical investigation on the EtOAc extract of the fermentation broth had led to the isolation of five new compounds, named altertoxins VIII-XII (1-5), as well as a known one, cladosporol I (6) [10] (Figure 1). All of the new compounds showed obvious QS inhibitory activities. Herein, the isolation, structure elucidation, and QS inhibitory activity of compounds $\mathbf{1 - 6}$ are described.<smiles>O=C1CCc2c3c4c(c(O)ccc4c4cccc1c24)CC[C@H]3O</smiles><smiles>OC1=CCCC2=C3CCCC3=c3c4cccc3=c3c-4ccc(O)c3=C12</smiles><smiles>CO[C@H]1CCc2c3c4c(c(O)ccc4c4cccc1c24)CCC3</smiles><smiles>O=C1CC[C@H](c2ccc(O)c3c2[C@H](O)CCC3=O)c2cccc(O)c21</smiles>

Figure 1. The chemical structures of compounds 1-6.

\section{Results and Discussions}

Compound 1 was obtained as a dark yellow powder, and its molecular formula was determined as $\mathrm{C}_{20} \mathrm{H}_{16} \mathrm{O}_{3}$ on the basis of HRESIMS data, indicating 13 degrees of unsaturation. The ${ }^{13} \mathrm{C}$ NMR and HSQC spectra showed 20 carbon signals assigned to four methylenes, 14 aromatic carbons with five protonated, one oxygenated $\mathrm{sp}^{3}$ methine, and a conjugated ketone carbonyl. Analysis of its ${ }^{1} \mathrm{H}$ and ${ }^{13} \mathrm{C}$ NMR data (Tables 1 and 2) revealed the presence of a 1,2,3-trisubstituted and a 1,2,3,4-tetrasubstituted benzene rings. The COSY correlations (Figure 2) of $\mathrm{H}_{2}-3 / \mathrm{H}_{2}-2$ and $\mathrm{H}-6 / \mathrm{H}-7$ along with the HMBC correlations from $\mathrm{H}_{2}-3\left(\delta_{\mathrm{H}} 2.84\right)$ to $\mathrm{C}-4\left(\delta_{\mathrm{C}} 204.8\right), \mathrm{C}-4 \mathrm{a}\left(\delta_{\mathrm{C}} 110.7\right), \mathrm{C}-1\left(\delta_{\mathrm{C}} 125.2\right)$ and $\mathrm{C}-2\left(\delta_{\mathrm{C}} 23.6\right)$, from $\mathrm{H}_{2}-2\left(\delta_{\mathrm{H}} 3.22\right)$ to $\mathrm{C}-8 \mathrm{a}\left(\delta_{\mathrm{C}} 131.0\right)$ and $\mathrm{C}-1$, from $\mathrm{H}-6\left(\delta_{\mathrm{H}} 7.13\right)$ to $\mathrm{C}-8\left(\delta_{\mathrm{C}} 121.3\right)$ and $\mathrm{C}-4 \mathrm{a}$, and from $\mathrm{H}-7\left(\delta_{\mathrm{H}} 8.92\right)$ to $\mathrm{C}-5\left(\delta_{\mathrm{C}} 161.8\right)$ and $\mathrm{C}-8 \mathrm{a}$, suggested the presence of a substituted 1-tetralone moiety. The observed COSY correlations of $\mathrm{H}-1^{\prime} / \mathrm{H}_{2}-2^{\prime} / \mathrm{H}_{2}-3^{\prime}$ as well as the HMBC correlations from $\mathrm{H}-1^{\prime}$ $\left(\delta_{\mathrm{H}} 4.80\right)$ to $\mathrm{C}-8^{\prime}$ a $\left(\delta_{\mathrm{C}} 139.7\right)$ and $\mathrm{C}-4^{\prime}$ a $\left(\delta_{\mathrm{C}} 126.1\right)$, from $\mathrm{H}_{2}-3^{\prime}\left(\delta_{\mathrm{H}} 2.96,3.15\right)$ to $\mathrm{C}-4^{\prime}\left(\delta_{\mathrm{C}} 132.9\right)$, from $\mathrm{H}_{2}-2^{\prime}\left(\delta_{\mathrm{H}} 1.84,2.06\right)$ to $\mathrm{C}-4^{\prime}$, from H-6 $\left(\delta_{\mathrm{H}} 8.52\right)$ to $\mathrm{C}-8^{\prime}\left(\delta_{\mathrm{C}} 123.8\right)$ and $\mathrm{C}-4^{\prime}$ a, and from $\mathrm{H}-7^{\prime}\left(\delta_{\mathrm{H}} 7.52\right)$ to $C-5^{\prime}\left(\delta_{C} 128.7\right)$ and $C-4^{\prime}$ a revealed the presence of a substituted 1-butanol moiety. Furthermore, the observed $\mathrm{HMBC}$ correlations from $\mathrm{H}_{2}-2$ to $\mathrm{C}-4^{\prime}$ and from $\mathrm{H}-3^{\prime}$ to $\mathrm{C}-1$ suggested that there is a C-1/C-4' linkage. The observed HMBC correlations from H-7 to C-5' and from H-6' to C-8 suggested that there is a $C-8 / C-5^{\prime}$ linkage. The above data revealed that compound 1 was structurally similar to altertoxin VII [11], except for the absence of a hydroxyl group located at C-7'. The ECD curve of $\mathbf{1}$ showed negative Cotton effects (CEs) around 225 and $260 \mathrm{~nm}$ and positive one around $280 \mathrm{~nm}$, which is very similar to that of altertoxin VII [11], suggesting their same absolute configuration, i.e., $1^{\prime} R$.

Compounds 2 and 3 were obtained as yellow powder, exhibiting two totally overlapped peaks over Rp-18 column and two independent peaks with a peak area ratio of 1:2 over a chiral column (Supporting information), suggesting that they are pair of enantiomers, which were different to each other at the absolute configuration in C-1'. Their formulas were determined as $\mathrm{C}_{20} \mathrm{H}_{18} \mathrm{O}_{2}$ on the basis of HRESIMS, indicating 12 degrees of unsaturation. Analysis of the 1D NMR data of 2 and 3 revealed that their planar structures are similar to that of $\mathbf{1}$, except that the C-4 carbonyl in $\mathbf{1}$ was replaced by a methylene in 2 and 3. This deduction was further confirmed by COSY correlations of $\mathrm{H}_{2}-2 / \mathrm{H}_{2}-3 / \mathrm{H}_{2}-4$. In order to determine the absolute configuration of the stereocenter $C-1^{\prime}$ of compounds 2 and 3, the ECD spectra of (R)-2 and (S)-2 were calculated and compared with the experimental ECD spectra of 2 and 3. As can be seen in Figure 3, the calculated ECD spectra for $(R)-\mathbf{2}$ and $(S)-\mathbf{2}$ matched well with the experimental ECD spectra of $\mathbf{2}$ and 3, respectively, indicating that the absolute configuration of $C-1^{\prime}$ in compound 2 is $R$ and in compound 3 is $S$. 
Table 1. ${ }^{1} \mathrm{H}$ (500 MHz) data of $\mathbf{1}-\mathbf{5}$ in DMSO.

\begin{tabular}{|c|c|c|c|c|}
\hline \multirow{2}{*}{ Position } & 1 & $2 / 3$ & 4 & 5 \\
\hline & $\delta_{\mathrm{H}}(J$ in $\mathrm{Hz})$ & $\delta_{\mathrm{H}}(J$ in $\mathrm{Hz})$ & $\delta_{\mathrm{H}}(J$ in $\mathrm{Hz})$ & $\delta_{\mathrm{H}}(J$ in $\mathrm{Hz})$ \\
\hline 1 & & & & $4.81, \mathrm{dd},(3.2,3.2)$ \\
\hline 2 & $3.22, \mathrm{t},(7.4)$ & $2.84, \mathrm{t},(6.0)$ & 2.92, overlap & $\begin{array}{l}2.01, \mathrm{~m} \\
2.05, \mathrm{~m}\end{array}$ \\
\hline 3 & $2.84, \mathrm{t},(7.4)$ & 1.80, overlap & $\begin{array}{c}1.81, \mathrm{~m} \\
1.92, \text { overlap }\end{array}$ & $\begin{array}{c}\text { 2.36, overlap } \\
2.97, \text { ddd, }(18.4,13.2,5.9)\end{array}$ \\
\hline 4 & & $\begin{array}{l}2.78, \text { overlap } \\
2.86, \text { overlap }\end{array}$ & $\begin{array}{c}2.78, \mathrm{~m} \\
2.90, \text { overlap }\end{array}$ & \\
\hline 6 & $7.13, \mathrm{~d},(9.1)$ & $7.04, \mathrm{~d},(9.0)$ & $7.11, \mathrm{~d},(9.0)$ & $6.76, d,(8.8)$ \\
\hline 7 & $8.92, \mathrm{~d},(9.1)$ & $8.32, \mathrm{~d},(9.0)$ & $8.40, \mathrm{~d},(9.0)$ & $7.31, \mathrm{~d},(8.8)$ \\
\hline $1^{\prime}$ & $4.80, \mathrm{dd},(3.6,8.4)$ & $4.74, \mathrm{dd},(8.3,3.7)$ & $4.47, \mathrm{~m}$ & 6.73, overlap \\
\hline $2^{\prime}$ & $\begin{array}{c}1.84, \mathrm{dtd},(13.0,8.7,4.7) \\
2.06, \mathrm{~m}\end{array}$ & $\begin{array}{l}\text { 1.78, overlap } \\
2.00, \mathrm{~m}\end{array}$ & $\begin{array}{l}\text { 1.97, overlap } \\
2.15, \mathrm{~m}\end{array}$ & 5.89, overlap \\
\hline $3^{\prime}$ & 2.96, ddd, $(16.7,9.0,4.8)$ & 2.82, overlap & 2.89 , overlap & $\begin{array}{c}2.29, \mathrm{ddd},(16.9,6.3,6.3) \\
2.47, \mathrm{~m}\end{array}$ \\
\hline $\begin{array}{l}4^{\prime} \\
5^{\prime}\end{array}$ & 3.15, ddd, $(16.7,7.0,4.8)$ & $3.02, \mathrm{~m}$ & $3.03, \mathrm{~m}$ & $\begin{array}{c}2.47, \mathrm{~m} \\
4.34, \mathrm{dd},(12.6,7.0) \\
5.89, \text { overlap }\end{array}$ \\
\hline $6^{\prime}$ & $8.52, \mathrm{~d},(8.3)$ & $8.39, \mathrm{~d},(8.3)$ & $8.53, \mathrm{~d},(8.4)$ & 6.74, overlap \\
\hline $7^{\prime}$ & $7.52, \mathrm{dd},(7.1,8.3)$ & $7.37, \mathrm{dd}(7.1,8.3)$ & $7.43, \mathrm{dd},(7.0,8.4)$ & $6.55, \mathrm{~d},(8.0)$ \\
\hline $8^{\prime}$ & $7.58, \mathrm{~d},(7.1)$ & $7.45, \mathrm{~d},(7.1)$ & $7.39, \mathrm{~d},(7.0)$ & \\
\hline $9^{\prime}$ & & & $3.24, \mathrm{~s}$ & \\
\hline $5-\mathrm{OH}$ & $13.15, \mathrm{~s}$ & & $9.52, \mathrm{~s}$ & $12.57, \mathrm{~s}$ \\
\hline $1^{\prime}-\mathrm{OH}$ & $5.40, \mathrm{~s}$ & $5.26, \mathrm{~s}$ & & $9.39, \mathrm{~s}$ \\
\hline
\end{tabular}

Table 2. ${ }^{13} \mathrm{C}$ NMR $(125 \mathrm{MHz})$ data of $\mathbf{1 - 5}$ in DMSO.

\begin{tabular}{|c|c|c|c|c|}
\hline Position & 1 & $2 / 3$ & 4 & 5 \\
\hline 1 & $125.2, \mathrm{C}$ & $128.7, \mathrm{C}$ & $129.3, \mathrm{C}$ & $61.3, \mathrm{CH}$ \\
\hline 2 & 23.6, $\mathrm{CH}_{2}$ & $27.1, \mathrm{CH}_{2}$ & 27.0, $\mathrm{CH}_{2}$ & $29.8, \mathrm{CH}_{2}$ \\
\hline 3 & $36.3, \mathrm{CH}_{2}$ & 21.9, $\mathrm{CH}_{2}$ & $21.8, \mathrm{CH}_{2}$ & $32.1, \mathrm{CH}_{2}$ \\
\hline 4 & $204.8, C$ & $23.4, \mathrm{CH}_{2}$ & $23.3, \mathrm{CH}_{2}$ & $206.3, C$ \\
\hline $4 a$ & $110.7, \mathrm{C}$ & $119.0, \mathrm{C}$ & $118.9, \mathrm{C}$ & $115.1, \mathrm{C}$ \\
\hline 5 & $161.8, \mathrm{C}$ & 152.1, C & $152.2, \mathrm{C}$ & $160.5, \mathrm{C}$ \\
\hline 6 & 117.0, $\mathrm{CH}$ & $115.5, \mathrm{CH}$ & $115.5, \mathrm{CH}$ & $117.2, \mathrm{CH}$ \\
\hline 7 & $133.4, \mathrm{CH}$ & $121.5, \mathrm{CH}$ & $121.5, \mathrm{CH}$ & 137.3, CH \\
\hline 8 & $121.3, \mathrm{C}$ & $122.2, \mathrm{C}$ & $122.1, \mathrm{C}$ & $132.9, \mathrm{C}$ \\
\hline $8 a$ & 131.0, C & $129.7, \mathrm{C}$ & $129.6, \mathrm{C}$ & $142.7, \mathrm{C}$ \\
\hline $1^{\prime}$ & $67.2, \mathrm{CH}$ & $67.6, \mathrm{CH}$ & $76.8, \mathrm{CH}$ & $121.9, \mathrm{CH}$ \\
\hline $2^{\prime}$ & $31.2, \mathrm{CH}_{2}$ & $31.5, \mathrm{CH}_{2}$ & $27.2, \mathrm{CH}_{2}$ & $125.9, \mathrm{CH}$ \\
\hline $3^{\prime}$ & 24.0, $\mathrm{CH}_{2}$ & $23.8, \mathrm{CH}_{2}$ & $22.5, \mathrm{CH}_{2}$ & $30.3, \mathrm{CH}_{2}$ \\
\hline $4^{\prime}$ & $132.9, \mathrm{C}$ & $127.9, \mathrm{C}$ & $127.5, \mathrm{C}$ & $37.5, \mathrm{CH}$ \\
\hline $4^{\prime} \mathrm{a}$ & $126.1, \mathrm{C}$ & $125.9, \mathrm{C}$ & 126.0, C & $139.4, \mathrm{C}$ \\
\hline $5^{\prime}$ & 128.7, C & $129.3, \mathrm{C}$ & 129.6, C & $117.9, \mathrm{CH}$ \\
\hline $6^{\prime}$ & 121.4, $\mathrm{CH}$ & $121.2, \mathrm{CH}$ & 122.2, $\mathrm{CH}$ & 127.7, $\mathrm{CH}$ \\
\hline $7^{\prime}$ & $126.2, \mathrm{CH}$ & $125.1, \mathrm{CH}$ & $124.6, \mathrm{CH}$ & $113.7, \mathrm{CH}$ \\
\hline $8^{\prime}$ & $123.8, \mathrm{CH}$ & $123.1, \mathrm{CH}$ & $125.2, \mathrm{CH}$ & $152.6, \mathrm{C}$ \\
\hline $8^{\prime} a$ & $139.7, \mathrm{C}$ & $139.2, \mathrm{C}$ & $134.1, \mathrm{C}$ & $121.2, \mathrm{C}$ \\
\hline $9^{\prime}$ & & & $55.2, \mathrm{CH}_{3}$ & \\
\hline
\end{tabular}




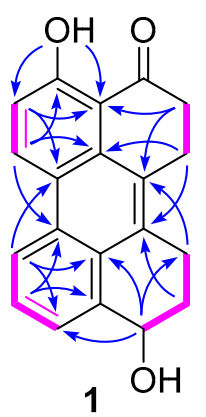

1

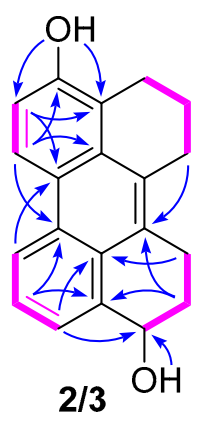

COSY
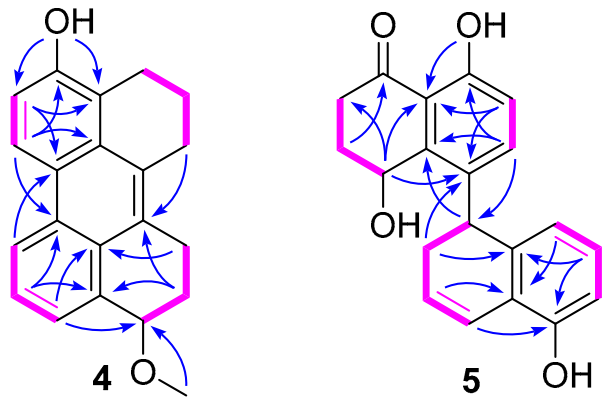

$\mathrm{HMBC}: \frown$

Figure 2. Key COSY and HMBC correlations of compounds 1-5.
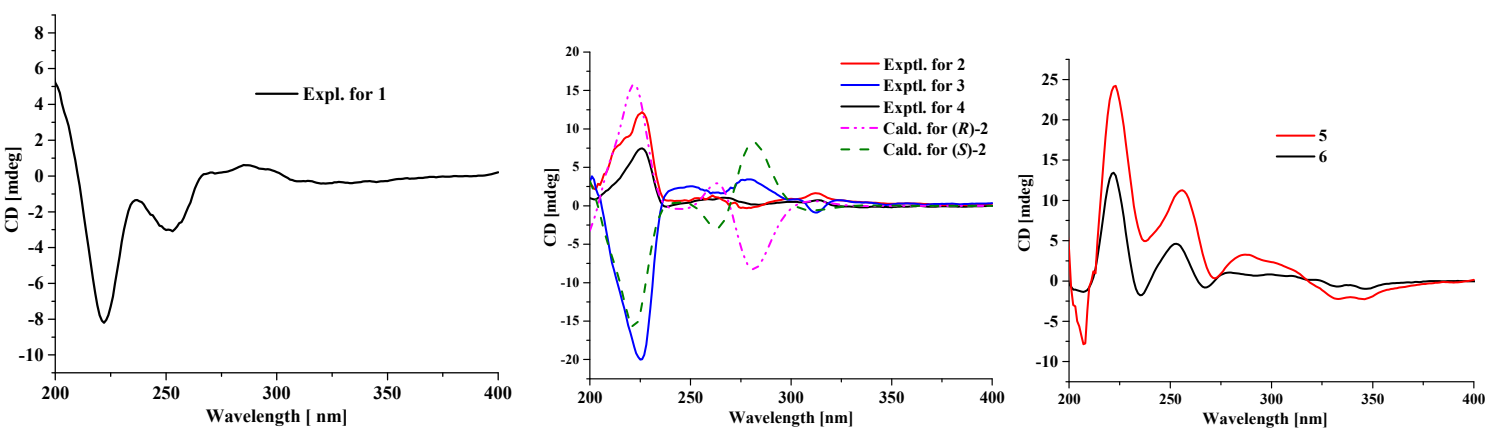

Figure 3. Experimental ECD spectra for compounds 1-6 and calculated ECD spectra for (R)-2 and (S)-2.

The molecular formula of compound 4 was determined as $\mathrm{C}_{21} \mathrm{H}_{20} \mathrm{O}_{2}$ based on HRESIMS, indicating 12 degrees of unsaturation. The ${ }^{13} \mathrm{C}$ NMR data of $\mathbf{4}$ are similar to those of $\mathbf{2}$ and $\mathbf{3}$ except for the presence of a methoxy carbon $\left(\delta_{C} 55.2\right)$ in 4 . In the HMBC spectrum, correlation from the protons of this carbon to $\mathrm{C}-1^{\prime}\left(\delta_{\mathrm{C}} 76.8\right)$ was observed, indicating that the $\mathrm{OH}-1^{\prime}$ in $\mathbf{2}$ or $\mathbf{3}$ was methylated in $\mathbf{4}$. The remaining substructure of 4 was determined to be the same as those of 2 and 3 by detailed analysis of its 2D NMR data (Figure 2). The absolute configuration of the stereocenter C-1' in 4 was determined to be the same as that of $\mathbf{2}$ by their similar ECD curves (Figure 3) and same sign of optical rotation values.

Compound 5 was obtained as yellow powder, and its formula was determined as $\mathrm{C}_{20} \mathrm{H}_{18} \mathrm{O}_{4}$ on the basis of HRESIMS data, indicating 12 degrees of unsaturation. Comprehensive analysis of the NMR data of 5 revealed that its structure is very similar to that of cladosporol I (6), except for the absence of the $C-1^{\prime}$ carbonyl and the presence of a double bond which was located at $C-1^{\prime}\left(\delta_{\mathrm{C}} 121.9\right)$ and $\mathrm{C}-2^{\prime}\left(\delta_{\mathrm{C}} 125.9\right)$ in 5 , as deduced from the COSY correlations of $\mathrm{H}-1^{\prime} / \mathrm{H}-2^{\prime} / \mathrm{H}-3^{\prime} / \mathrm{H}-4^{\prime}$ as well as the HMBC correlations from $\mathrm{H}_{2}-3^{\prime}\left(\delta_{\mathrm{H}} 2.29,2.47\right)$ to $\mathrm{C}-1^{\prime}$ and $\mathrm{C}-4^{\prime}$ a $\left(\delta_{\mathrm{C}} 139.4\right)$ and from $\mathrm{H}-2^{\prime}\left(\delta_{\mathrm{H}} 5.89\right)$ to $\mathrm{C}-4^{\prime}\left(\delta_{\mathrm{C}} 37.5\right)$ and $\mathrm{C}-8^{\prime} \mathrm{a}\left(\delta_{\mathrm{C}} 121.2\right)$. The absolute stereochemistry of the asymmetric $\mathrm{C}-4^{\prime}$ was estimated from the ECD spectrum. In the ECD spectrum of 5, there was a strong splitting cotton effect centered at $216 \mathrm{~nm}$, which should be originated from exciton chirality caused by interaction between two phenolic chromophores [12]. Thus, according to the exciton chirality rule, the absolute stereochemistry of C- $4^{\prime}$ was determined to be $S$. In addition, the absolute configuration of the C-1 stereocenter in cladosporol I (6) has been determined by comparison of the experimental ECD curve with the calculated ECD curves of the two C-1 epimers (1R,4S)-6 and (1S,4S)-6 [8]. According the results, the calculated ECD curve for $(1 S, 4 S)-6$ showed an intense positive $C E$ around $225 \mathrm{~nm}$, which matched well with the experimental one and was absent in the calculated ECD curve for $(1 R, 4 S)-6$. Thus, the intense positive CE around $225 \mathrm{~nm}$ can be used to differentiate $(1 R, 4 S)-\mathbf{6}$ and $(1 S, 4 S)-\mathbf{6}$. The experimental ECD curve of $\mathbf{5}$, with an intense positive $C E$ around $225 \mathrm{~nm}$, is very similar to that of $(1 S, 4 S)-6$, indicating that the absolute configuration of $C-1$ is $S$, same as that of 6 . 
All the isolated compounds were tested for QS inhibitory activity against Chromobacterium violaceum CV026 [6]. Compounds 1-6 showed obvious activities (Figure S34, Supporting Information) and the minimum inhibitory concentration (MIC) values were finally determined to be 30, 30, 20, 30, 20 and $30 \mu \mathrm{g} /$ well, respectively.

\section{Experimental}

\subsection{General Experimental Procedures}

The NMR spectra were recorded with a Bruker AV-500 spectrometer (Bruker, Bremen, Germany) using TMS as an internal standard. The mass spectrometric (HRESIMS) data were acquired using an API QSTAR Pulsar mass spectrometer (Bruker, Bremen, Germany). Optical rotations were measured with a JASCO P-1020 digital polarimeter (Anton Paar, Graz, Austria). The infrared spectra were recorded on a Shimadzu UV2550 spectrophotometer (Shimadzu, Kyoto, Japan). Silica gel (60-80 and 200-300 mesh; Qingdao Haiyang Chemincal Co. Ltd., Qingdao, China) and Rp-C18 (20-45 $\mu \mathrm{m}$; Fuji Silysia Chemical Ltd., Durham, NC, USA) were used for column chromatography. Semipreparative high-performance liquid chromatography (HPLC) equipped with octadecyl silane (ODS) column (Cosmosil ODS-A, $10 \times 250 \mathrm{~nm}, 5 \mu \mathrm{m}, 4 \mathrm{~mL} / \mathrm{min}$ ) and chiral column (CHIRALPAK IC, $4.6 \times 250 \mathrm{~nm}$, $5 \mu \mathrm{m}, 1 \mathrm{~mL} / \mathrm{min}$ ) were used for purification of compounds. The solvents used for the purification of compounds, such as ethyl acetate, methanol, chloroform and methanol, were of analytical pure (Concord Technology Co. Ltd., Tianjin, China).

\subsection{Fungus Material}

The fungal strain Cladosporium sp. KFD33 with yellow mycelium was isolated from a blood cockle in the Haikou Bay, Hainan province, in China in August 2018. After grinding, the sample (1 g) was diluted to $10^{-2} \mathrm{~g} / \mathrm{mL}$ with sterile $\mathrm{H}_{2} \mathrm{O}, 100 \mu \mathrm{L}$ of which was spread on a PDA medium plate containing chloramphenicol as bacterial inhibitor. It was identified by its morphological characteristics and $18 \mathrm{~S}$ rRNA gene sequences (GenBank accessing No. MN737504, Supporting Information), the used primers of which were NS1 (GTAGTCATATGCTTGTCTC) and NS6 (GCATCACAGACCTGTTATTGCCTC). A reference culture of Cladosporium sp. KFD33 is deposited in our laboratory and which maintained at $-80{ }^{\circ} \mathrm{C}$.

\subsection{Culture Conditions}

Plugs of agar, supporting mycelial growth, were cut from solid culture medium and transferred aseptically to a $1000 \mathrm{~mL}$ Erlenmeyer flask, containing $300 \mathrm{~mL}$ liquid medium (peptone $5 \mathrm{~g} / \mathrm{L}$, yeast extract $2 \mathrm{~g} / \mathrm{L}$, glucose $20 \mathrm{~g} / \mathrm{L}, \mathrm{MgSO}_{4} 0.5 \mathrm{~g} / \mathrm{L}, \mathrm{KH}_{2} \mathrm{PO}_{4} 2 \mathrm{~g} / \mathrm{L}, \mathrm{pH}$ 6.5). The fungus was cultured under static conditions at room temperature for 30 days on the shelf of our laboratory.

\subsection{Extraction and Isolation}

The whole culture broth $(20 \mathrm{~L})$ was harvested and filtered to yield the mycelium cake and liquid broth. The mycelium cake and liquid broth were extracted by EtOAc for three times, respectively. The EtOAc solution was evaporated under reduced pressure. A total of $10 \mathrm{~g}$ EtOAc extract was obtained. The EtOAc extract was submitted to silica gel vacuum liquid chromatography using step gradient elution with PE/EtOAc (8:1, 6:1, 4:1, 2:1, 1:1, 0:1, v/v) to obtain six fractions (Frs.1-6) based on HPLC analysis. Fr.1 (2 g) was further chromatographed on $\mathrm{Rp}^{-\mathrm{C}_{18}}$ silica gel column eluted with $\mathrm{MeOH} / \mathrm{H}_{2} \mathrm{O}$ (from 10\%-100\%) to give three subfractions (Fr.1-1-Fr.1-3). Compound 1 (1.0 mg, $\mathrm{t}_{\mathrm{R}}$ $25.9 \mathrm{~min}), 5\left(1.1 \mathrm{mg}, \mathrm{t}_{\mathrm{R}} 10.0 \mathrm{~min}\right)$, and 6 (5.3 $\left.\mathrm{mg}, \mathrm{t}_{\mathrm{R}} 19.6 \mathrm{~min}\right)$ were obtained from Fr.1-1 (15.0 mg) by ODS chromatography eluting with $\mathrm{MeOH}-\mathrm{H}_{2} \mathrm{O}(10 \%-100 \%)$ and semipreparative HPLC (40\% $\mathrm{MeOH} / \mathrm{H}_{2} \mathrm{O}$, containing $0.1 \%$ Formic acid, $\left.4.0 \mathrm{~mL} \cdot \mathrm{min}^{-1}\right)$. The mixture of compounds 2 and $3(2.1 \mathrm{mg}$, $\left.\mathrm{t}_{\mathrm{R}} 10.7 \mathrm{~min}\right)$ and $4\left(1.9 \mathrm{mg}, \mathrm{t}_{\mathrm{R}} 32.2 \mathrm{~min}\right)$ were obtained from Fr.1-2 (6.3 mg) by ODS chromatography eluting with $\mathrm{MeOH} / \mathrm{H}_{2} \mathrm{O}(10 \%-100 \%)$ and semipreparative $\mathrm{HPLC}\left(65 \% \mathrm{MeOH} / \mathrm{H}_{2} \mathrm{O}\right.$, containing $0.1 \%$ 
Formic acid, $\left.4.0 \mathrm{~mL} \cdot \mathrm{min}^{-1}\right)$. Compounds $2\left(0.3 \mathrm{mg}, \mathrm{t}_{\mathrm{R}} 24.6 \mathrm{~min}\right)$ and $3\left(0.5 \mathrm{mg}, \mathrm{t}_{\mathrm{R}} 27.2 \mathrm{~min}\right)$ were further obtained from their mixture by semipreparative HPLC $\left(99 \%\right.$ Hexane/EtOH, $\left.1.0 \mathrm{~mL} \cdot \mathrm{min}^{-1}\right)$, using a chiral column.

Altertoxin VIII (1): Dark yellow powder; $[\alpha]_{\mathrm{D}}^{25}-9.0(c$ 0.1, $\mathrm{MeOH}) ; \mathrm{UV}\left(\mathrm{CH}_{3} \mathrm{OH}\right) \lambda_{\max }(\log \varepsilon)$ : 252 (3.16) $\mathrm{nm} ; 217$ (2.97); $\mathrm{ECD}\left(\mathrm{CH}_{3} \mathrm{OH}\right) \lambda_{\max }(\Delta \varepsilon): 222(-1.94) \mathrm{nm} ; 237(-0.32) \mathrm{nm} ; 250(-0.71) \mathrm{nm} ; 270(0.05)$ $\mathrm{nm} ; 322(-0.10) \mathrm{nm} ; \mathrm{IR}(\mathrm{KBr}) v_{\max }: 3418,2924,2856,1625,1415,1027 \mathrm{~cm}^{-1} ;{ }^{1} \mathrm{H}$ and ${ }^{13} \mathrm{C}$ NMR spectral data, Tables 1 and 2; HRESIMS $\mathrm{m} / \mathrm{z} 327.0985\left([\mathrm{M}+\mathrm{Na}]^{+}\right.$calcd 327.0992).

Altertoxin IX (2): Yellow powder; $[\alpha]_{\mathrm{D}}^{25}+35.0(c \mathrm{c} 0.01, \mathrm{MeOH}) ; \mathrm{UV}\left(\mathrm{CH}_{3} \mathrm{OH}\right) \lambda_{\max }(\log \varepsilon): 264(3.14) \mathrm{nm}$; $\mathrm{ECD}\left(\mathrm{CH}_{3} \mathrm{OH}\right) \lambda_{\max }(\Delta \varepsilon): 226(16.08) \mathrm{nm} ; 261(1.77) \mathrm{nm} ; 278(-0.39) \mathrm{nm} ; 312$ (2.16) nm; IR(KBr) $v_{\max }$ : $3437,2925,1569,1415 \mathrm{~cm}^{-1} ;{ }^{1} \mathrm{H}$ and ${ }^{13} \mathrm{C}$ NMR spectral data, Tables 1 and 2; HRESIMS m/z 313.1186 $\left([\mathrm{M}+\mathrm{Na}]^{+}\right.$calcd 313.1199).

Altertoxin X (3): Yellow powder; $[\alpha]_{\mathrm{D}}^{25}-34.0(c 0.01, \mathrm{MeOH}) ; \mathrm{UV}\left(\mathrm{CH}_{3} \mathrm{OH}\right) \lambda_{\max }(\log \varepsilon): 264$ (3.14) nm; $\mathrm{ECD}\left(\mathrm{CH}_{3} \mathrm{OH}\right) \lambda_{\max }(\Delta \varepsilon): 225(-9.23) \mathrm{nm} ; 250(1.18) \mathrm{nm} ; 265$ (1.56) nm; $276(-0.41) \mathrm{nm} ; 312(-0.41)$ $\mathrm{nm} ; 324(0.34) \mathrm{nm} ; \mathrm{IR}(\mathrm{KBr}) v_{\max }: 3437,2925,1569,1415 \mathrm{~cm}^{-1} ;{ }^{1} \mathrm{H}$ and ${ }^{13} \mathrm{C}$ NMR spectral data, Tables 1 and 2; HRESIMS $\mathrm{m} / \mathrm{z} 313.1186\left([\mathrm{M}+\mathrm{Na}]^{+}\right.$calcd 313.1199).

Altertoxin XI (4): Yellow powder; $[\alpha]_{\mathrm{D}}^{25}+18.0$ (c 0.01, $\left.\mathrm{MeOH}\right)$; $\mathrm{UV}\left(\mathrm{CH}_{3} \mathrm{OH}\right) \lambda_{\max }(\log \varepsilon): 264(3.16) \mathrm{nm}$; $\mathrm{ECD}\left(\mathrm{CH}_{3} \mathrm{OH}\right) \lambda_{\max }(\Delta \varepsilon): 226(3.44) \mathrm{nm} ; 238(-0.05) \mathrm{nm} ; 267(0.48) \mathrm{nm} ; 284(0.06) \mathrm{nm} ; 314(0.34) \mathrm{nm} ;$ $336(-0.09) \mathrm{nm}$; IR (KBr) $v_{\max }: 3440,2924,2854,1689,1584,1418,1207 \mathrm{~cm}^{-1} ;{ }^{1} \mathrm{H}$ and ${ }^{13} \mathrm{C}$ NMR spectral data, Tables 1 and 2; HRESIMS m/z $327.1342\left([\mathrm{M}+\mathrm{Na}]^{+}\right.$calcd 327.1356).

Altertoxin XII (5): Yellow powder; $[\alpha]_{\mathrm{D}}^{25}+61.0($ c 0.01, $\mathrm{MeOH}) ; \mathrm{UV}\left(\mathrm{CH}_{3} \mathrm{OH}\right) \lambda_{\max }(\log \varepsilon): 261$ (3.21) nm; $\mathrm{ECD}\left(\mathrm{CH}_{3} \mathrm{OH}\right) \lambda_{\max }(\Delta \varepsilon): 207(-4.32) \mathrm{nm} ; 223(13.32) \mathrm{nm} ; 237(2.71) \mathrm{nm} ; 256$ (6.19) nm; 272 (0.18) nm; $287(1.80) \mathrm{nm} ; 346(-1.24) \mathrm{nm}$; IR (KBr) $v_{\max }$ : 3442, 2923, 2851, 1636, 1453, 1355, 1235, $807 \mathrm{~cm}^{-1} ;{ }^{1} \mathrm{H}$ and ${ }^{13} \mathrm{C}$ NMR spectral data, Tables 1 and 2; HRESIMS m/z $361.0856\left([\mathrm{M}+\mathrm{K}]^{+}\right.$calcd 361.0837).

\subsection{QS Inhibitory Assays of C. Violaceum CV026}

An overnight culture of $C$. violaceum CV026 [9] in LB broth $\left(\mathrm{OD}_{600} \approx 1.0\right)$ was prepared. Then $15 \mathrm{~mL}$ LB agar plate were flooded with $1 \mathrm{~mL}$ of this culture and C6-HSL at concentration of $500 \mathrm{nM}$ to prepare an agar plate as a lawn. 5-mm diameter wells were bored in the agar plate using a flame-sterilized glass tube and the compounds dissolved in DMSO were added to the wells respectively. These plates were then incubated at $30^{\circ} \mathrm{C}$ for $18 \mathrm{~h}$. Inhibition of QS in C. violaceum is manifested as the inhibition of purple pigmentation around the wells containing the compounds

\section{Conclusions}

In conclusion, we found five new altertoxins with QS inhibitory activities against Chromobacterium violaceum CV026 from the marine-derived fungus Cladosporium sp. KFD33. These compounds represent a new type of QSIs, and can be used as lead compounds for developing new QSIs drugs, which can disarm pathogens without causing resistance of bacteria.

Supplementary Materials: The following are available online at http://www.mdpi.com/1660-3397/18/1/67/s1, Figures S1-S31: 2D NMR, IR, and HRESIMS spectra of the new compounds 1-5, the 18S rRNA gene sequence of Cladosporium sp. KFD33 as well as the picture of quorum sensing inhibitory activity of compounds 1-6 against Chromobacterium violaceum CV026 are supplied.

Author Contributions: F.Z. contributed to the fungal isolation, fermentation, and compounds purification. F.K. and L.Z. were responsible for the structural elucidation and chemical computation. Q.M. and Q.X. contributed to the bioassays. J.L. and H.D. revised the paper. Y.Z. and L.G. designed the work and revised the paper. All authors have read and agreed to the published version of the manuscript.

Funding: This work was supported by Natural Science Foundation of Hainan Province (2019CXTD411), Natural Science Foundation of China (81973568, 41606088), Financial Fund of the Ministry of Agriculture and Rural Affairs, P. R. of China (NFZX2018), China Agriculture Research System (CARS-21), and Central Public-interest Scientific Institution Basal Research Fund for Chinese Academy of Tropical Agricultural Sciences (17CXTD-15, 
1630052016008, 1630052020012), and Priority Academic Program Development of Jiangsu Higher Education Institutions (PAPD).

Conflicts of Interest: The authors declare no conflict of interest.

\section{References}

1. Fukumoto, A.; Murakami, C.; Anzai, Y.; Kato, F. Maniwamycins: New quorum-sensing inhibitors against Chromobacterium violaceum CV026 were isolated from Streptomyces sp. TOHO-M025. J. Antibiot. 2016, 69, 395. [CrossRef] [PubMed]

2. Rasmussen, T.B.; Skindersoe, M.E.; Bjarnsholt, T.; Phipps, R.K.; Christensen, K.B.; Jensen, P.O.; Andersen, J.B.; Koch, B.; Larsen, T.O.; Hentzer, M.; et al. Identity and effects of quorum-sensing inhibitors produced by Penicillium species. Microbiology 2005, 151, 1325-1340. [CrossRef] [PubMed]

3. LaSarre, B.; Federle, M.J. Exploiting quorum sensing to confuse bacterial pathogens. Microbiol. Mol. Biol. Rev. 2013, 77, 73-111. [CrossRef] [PubMed]

4. Miller, M.B.; Bassler, B.L. Quorum sensing in bacteria. Annu. Rev. Microbiol 2001, 55, 165-199. [CrossRef] [PubMed]

5. Kalia, V.C.; Patel, S.K.; Kang, Y.C.; Lee, J.K. Quorum sensing inhibitors as antipathogens: Biotechnological applications. Biotechnol. Adv. 2019, 37, 68-90. [CrossRef] [PubMed]

6. Huang, S.Z.; Cheng, B.H.; Ma, Q.Y.; Wang, Q.; Kong, F.D.; Dai, H.F.; Qiu, S.Q.; Zheng, P.Y.; Liu, Z.Q.; Zhao, Y.X. Anti-allergic prenylated hydroquinones and alkaloids from the fruiting body of Ganoderma calidophilum. RSC Adv. 2016, 6, 21139-21147. [CrossRef]

7. Carroll, A.R.; Copp, B.R.; Davis, R.A.; Keyzers, R.A.; Prinsep, M.R. Marine natural products. Nat. Prod. Rep. 2014, 31, 160-258. [CrossRef] [PubMed]

8. Kong, F.D.; Zhou, L.M.; Ma, Q.Y.; Huang, S.Z.; Wang, P.; Dai, H.F.; Zhao, Y.X. Metabolites with Gram-negative bacteria quorum sensing inhibitory activity from the marine animal endogenic fungus Penicillium sp. SCS-KFD08. Arch. Pharm. Res. 2017, 40, 25-31. [CrossRef] [PubMed]

9. Zhang, F.; Kong, F.D.; Ma, Q.Y.; Xie, Q.Y.; Zhou, L.M.; Zhao, Y.X.; Guo, L. Polyketides with quorum sensing inhibitory activity from the marine-derived fungus Aspergillus sp. ZF-79. J. Asian Nat. Prod. Res. 2019, 1-7. [CrossRef] [PubMed]

10. Li, H.L.; Li, X.M.; Mándi, A.; Antus, S.; Li, X.; Zhang, P.; Liu, Y.; Kurtán, T.; Wang, B.G. Characterization of cladosporols from the marine algal-derived endophytic fungus Cladosporium cladosporioides EN-399 and configurational revision of the previously reported cladosporol derivatives. J. Org. Chem. 2017, 82, 9946-9954. [CrossRef] [PubMed]

11. Pang, X.Y.; Lin, X.P.; Wang, P.; Zhou, X.F.; Yang, B.; Wang, J.F.; Liu, Y.H. Perylenequione Derivatives with Anticancer Activities Isolated from the Marine Sponge-Derived Fungus, Alternaria sp. SCSIO41014. Mar. Drugs 2018, 16, 280. [CrossRef] [PubMed]

12. Sekiguchi, J.; Gaucher, G.M. Isoepoxydon, a new metabolite of the patulin pathway in Penicillium urticae. Biochem. J. 1979, 182, 445-453. [CrossRef] [PubMed]

(C) 2020 by the authors. Licensee MDPI, Basel, Switzerland. This article is an open access article distributed under the terms and conditions of the Creative Commons Attribution (CC BY) license (http://creativecommons.org/licenses/by/4.0/). 